Jurnal Indonesia Sosial Teknologi: p-ISSN: 2723 - 6609

e-ISSN : 2745-5254

Vol. 2, No. 7 Juli 2021

\title{
MUTU PAPAN PARTIKEL DARI CAMPURAN BATANG DAN CANGKANG KELAPA SAWIT (Elaeis Guineensis Jacq) DENGAN PENGGUNAAN RESIN
}

\author{
Calvin Davidson Silalahi ${ }^{1}$, Rama R. Sitinjak ${ }^{2}$, dan Bayu Pratomo ${ }^{3}$ \\ Program Studi Agroteknologi, Fakultas Agro Teknologi, Universitas Prima Indonesia, \\ Medan \\ Email: sitinjakrama@yahoo.co.id ${ }^{2}$, bayupratomo@unprimdn.ac.id ${ }^{3}$
}

\begin{abstract}
Abstrak
Saat ini kebutuhan bahan papan terus mengalami peningkatan biasanya bahan papan ini merupakan bahan yang diperoleh dari hutan. Salah satu Tujuan yang dilakukan adalah dengan menggantikan kayu dengan material lain seperti papan partikel untuk memenuhi kebutuhan kayu pada bidang perumahan. Metode yang digunakan dalam penelitian ini adalah cangkang dan batang kelapa sawit dan resin. Cangkang dan batang yang telah dihaluskan dicampur dalam wadah dan diaduk sesuai Komposisi. Berdasarkan penelitian yang telah dilakukan dapat diambil kesimpulan bahwa hasil penelitian menunjukkan adanya pengaruh kecuali pada daya serap air dan modulus of elasticity pada komposisi papan partikel. Pada pengukuran sifat fisis dan mekanis didapatkan papan dengan kualitas terbaik pada komposisi 90\%:10\% dengan nilai kerapatan sebesar $1,10 \mathrm{~g} / \mathrm{cm}^{3}$, nilai kadar air 1,01\%, nilai pengembangan tebal terbaik sebesar 0,56\%, nilai MOE terbaik sebesar $30,515 \mathrm{~kg} / \mathrm{cm}^{2}$ pada komposisi 90\%:10\%, dan nilai MOR sebesar $236,99 \mathrm{~kg} / \mathrm{cm}^{2}$. Hasil penelitian menunjukkan bahwa pengujian sifat fisis dan mekanis papan partikel telah memenuhi standard SNI 03 2105-2006.
\end{abstract}

Kata kunci: papan partikel; komposisi bahan baku; uji fisis dan mekanis.

\section{Abstract}

Currently, the need for board materials continues to increase, usually these board materials are materials obtained from the forest. One of the objectives is to replace wood with other materials such as particle board to meet the demand for wood in the housing sector. The method used in this research is oil palm shell and trunk and resin. The crushed shells and stems are mixed in a container and stirred according to the composition. Based on the research that has been done, it can be concluded that the results of the research show that there is an effect except on the water absorption and modulus of elasticity on the composition of the particle board. In the measurement of physical and mechanical properties, the board with the best quality is $90 \%: 10 \%$ with a density value of $1.10 \mathrm{~g} / \mathrm{cm}^{3}$, a moisture content value of $1.01 \%$, the best thickness expansion value of $0.56 \%$, the best MOE value. of $30.515 \mathrm{~kg} / \mathrm{cm}^{2}$ at 90\%:10\% composition, and the MOR value is $236.99 \mathrm{~kg} / \mathrm{cm}^{2}$. The results showed that the physical and mechanical properties of particleboard had met the standards of SNI 03-2105-2006 
Keywords: particle board; composition of raw materials; physical and mechanical tests.

\section{Pendahuluan}

Saat ini kebutuhan bahan papan terus mengalami peningkatan biasanya bahan papan ini merupakan bahan yang diperoleh dari hutan. Meningkatnya pemakaian kebutuhan akan papan ini dapat memberikan pengaruh yang kurang baik, yaitu hasil hutan terutama bahan kayu lama kelamaan akan semakin berkurang. Ketergantungan akan bahan kayu harus segera ditanggulangi, agar tidak mengurangi hasil hutan. Salah satu upaya yang dilakukan adalah dengan menggantikan kayu dengan material lain seperti papan partikel untuk memenuhi kebutuhan kayu pada bidang perumahan. Material lain yang digunakan ini tentunya harus mempunyai kualitas yang unggul atau tidak kalah dengan produk kayu hutan tersebut (Johari, Kardiman, \& Santoso, 2021). Batang dan cangkang kelapa sawit merupakan bahan yang mengandung lignoselulosa yang memliki potensi yang besar untuk dijadikan papan partikel yang berkualitas. Kelapa sawit dipanen terus sampai pohon berumur 30 tahun, dan pada umur 35 tahun perlu replanting dan batang kelapa sawit yang direplanting akan menjadi limbah. Cangkang kelapa sawit merupakan salah satu limbah yang jumlahnya mencapai $60 \%$ dari produksi minyak inti (Diharyo, Damanik, \& Gumiri, 2020). Limbah kedua bahan tersebut dapat dioptimalkan untuk dibuat papan partikel yang berkualitas.

Papan partikel merupakan hasil pengempaan panas dari kombinasi partikel kayu ataupun bahan yang memiliki lignoselulosa dengan perekat. Adapun kelebihan dari papan partikel dibandingkan kayu asalnya yaitu papan partikel bebas dari mata kayu, pecah/retak, tebalnya seragam, mudah dikerjakan. Papan partikel yang dihasilkan biasanya mempunyai dimensi, tebal serta kerapatan yang seragam, sifat serta kualitasnya juga dapat diatur (Iskandar \& Supriadi, 2017).

Penelitian pemanfaatan kayu sawit telah dilakukan oleh (Mawardi, 2009), menunjukan cara pemanfaatan KKS paling tepat adalah bagian kayu kelapa sawit yang digunakan adalah bagian batang yang mempunyai ketinggian di atas 2 meter. Kayu kelapa sawit dibersihkan dari kotoran dan dihancurkan menjadi partikel dengan ukuran $<5 \mathrm{~mm}$. Penelitian tersebut memberikan hasil bahwa komposisi partikel kayu kelapa sawit berpengaruh terhadap sifat mekanis yang dihasilkan. Papan partikel kayu kelapa sawit memiliki nilai kekuatan tarik optimum sebesar $55,15 \mathrm{~kg} / \mathrm{cm} 2$ dan kekuatan lentur optimum sebesar $92,27 \mathrm{~kg} / \mathrm{cm}$. Secara umum papan partikel KKS-PS telah memenuhi persyaratan standar SNI 03-2105-2006.

\section{Metode Penelitian}

Bahan yang digunakan dalam penelitian ini adalah cangkang dan batang kelapa sawit dan resin. Cangkang dan batang yang telah dihaluskan dicampur dalam wadah dan diaduk sesuai Komposisi. Komposisi cangkang dan batang kelapa sawit memiliki 9 variasi diantaranya : 90:10\%, 80:20\%, 70:30\%, 60:40\%, 50:50\%, 40:60\%, 30:70\%, 20:80\%, dan 10:90\% dengan komposisi perekat yang tetap 50\%. Sampel yang telah 
diaduk dituangkan dalam cetakan yang sudah dilapisi aluminium foil. Permukaan sampel diratakan dengan penutup yang tersedia pada cetakan dan ditekan menggunakan hot packing press dengan $150^{\circ} \mathrm{C}$ selama 10 menit. Kemudian Papan yang telah jadi, dikondisikan dan didiamkan hingga \pm 7 hari pada temperatur kamar supaya menyeragamkan kandungan air dan melenyapkan tegangan pada papan. Kemudian dilakukan uji sifat fisis dan uji mekanis. Pengujian sifat fisis dan mekanik papan partikel dilakukan berdasarkan standar SNI 03- 2105-2006. Parameter uji sifat fisis yang akan dilakukan adalah Kerapatan, Kadar air, Daya serap air, Pengembangan tebal, Modulus of elasticity (MOE), Modulus of rupture (MOR), Keteguhan Rekat (IB). Data dari hasil pengamatan di analisi dengan Analysis of Variance (ANOVA) apabila hasil perlakuan ini berpengaruh nyata, maka akan dilakukan pengujian lebih lanjut dengan taraf $5 \%$ dengan menggunakan SPSS versi 2.2.

\section{Hasil dan Pembahasan \\ Kerapatan}

Nilai rataan kerapatan papan partikel dari canhgkang dan batang kelapa sawit, dengan menggunakan perekat resin terdapat pada gambar 1 .

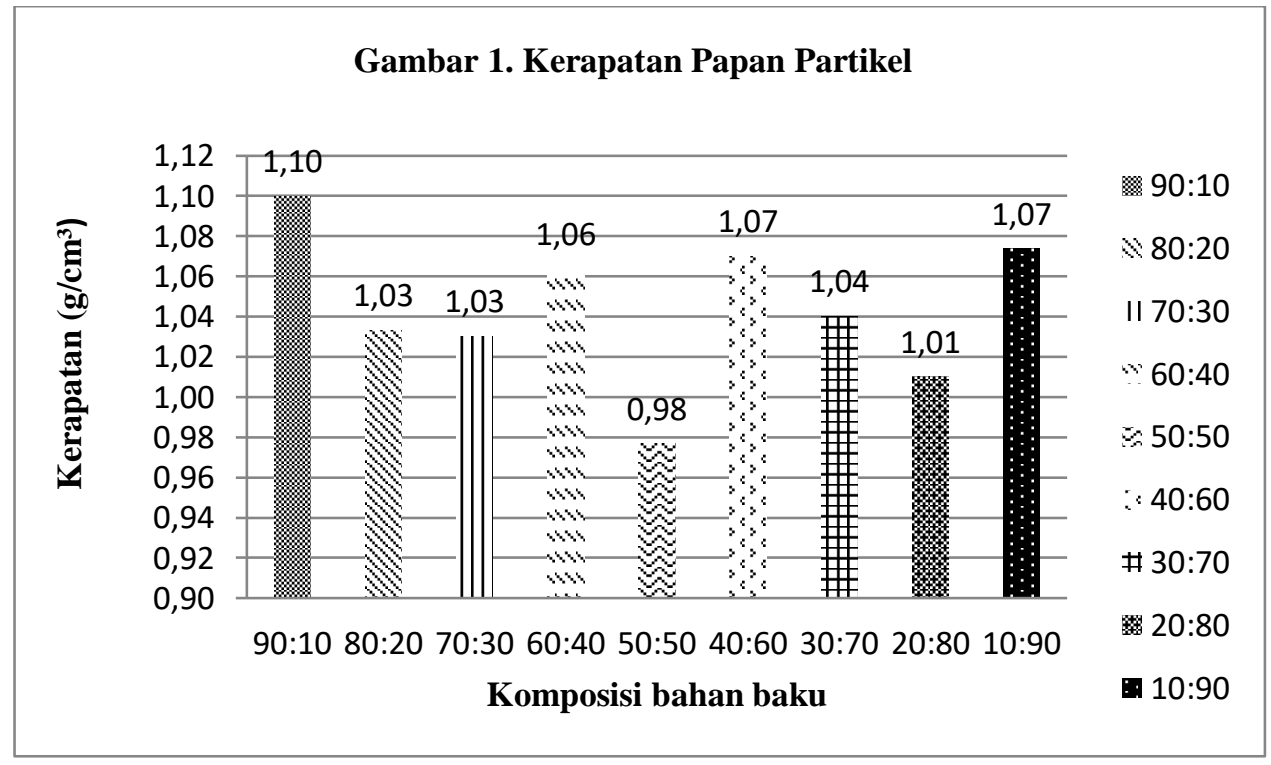

Gambar 1 menunjukkan nilai kerapatan papan partikel yang dihasilkan antara 0,98-1,10 $\mathrm{g} / \mathrm{cm}^{3}$. Kerapatan terendah papan partikel terdapat pada papan dengan komposisi 50\%:50\% dengan kerapatan $0,98 \mathrm{~g} / \mathrm{cm}^{3}$, sedangkan nilai kerapatan tertinggi papan partikel terdapat pada komposisi 90\%:10\% dengan kerapatan 1,06 g/cm³ . Hasil penelitian ini menunjukkan bahwa semua papan partikel yang dihasilkan dengan kerapatan $0,98-1,10 \mathrm{~g} / \mathrm{cm}^{3}$ termasuk dalam kategori papan partikel berkerapatan tinggi dan telah memenuhi SNI.03-2105-2006 yang mensyaratkan nilai kerapatannya adalah 0,4 $\mathrm{g} / \mathrm{cm} 3$ sampai $0,9 \mathrm{~g} / \mathrm{cm} 3$. Nilai kerapatan yang lebih tinggi diperoleh saat dikempa pada waktu yang lebih lama yaitu 15 menit. Hal ini menunjukkan bahwa lama waktu pengempaan dapat meningkatkan kerapatan atau ikatan antar serat. Waktu kempa yang 
semakin lama memberikan peluang antar partikel untuk saling kontak dengan baik dan menjadi lebih mampat (Ngadianto, Aryo F, 2016). Pencampuran partikel dan perekat juga berpengaruh terhadap kerapatan papan partikel. Terdapat rongga rongga pada papan partikel apabila pecampuran kurang tepat (Radam, Soendjoto, Rezekiah, \& Agustina, 2018). Kerapatan papan partikel juga akan berpengaruh terhadap konsentrasi yang diberikan (Raharjo, 2020). Kerapatan bahan baku yang rendah lebih baik digunakan agar membentuk papan partikel yang lebih solid (Sudiryanto, 2015).

\section{Kadar air}

Nilai kadar air yang disyaratkan dalam SNI 03-2105-2006 tentang papan partikel yaitu sebesar $\leq 14 \%$. Hasil pengujian kadar air disajikan pada gambar 2 .

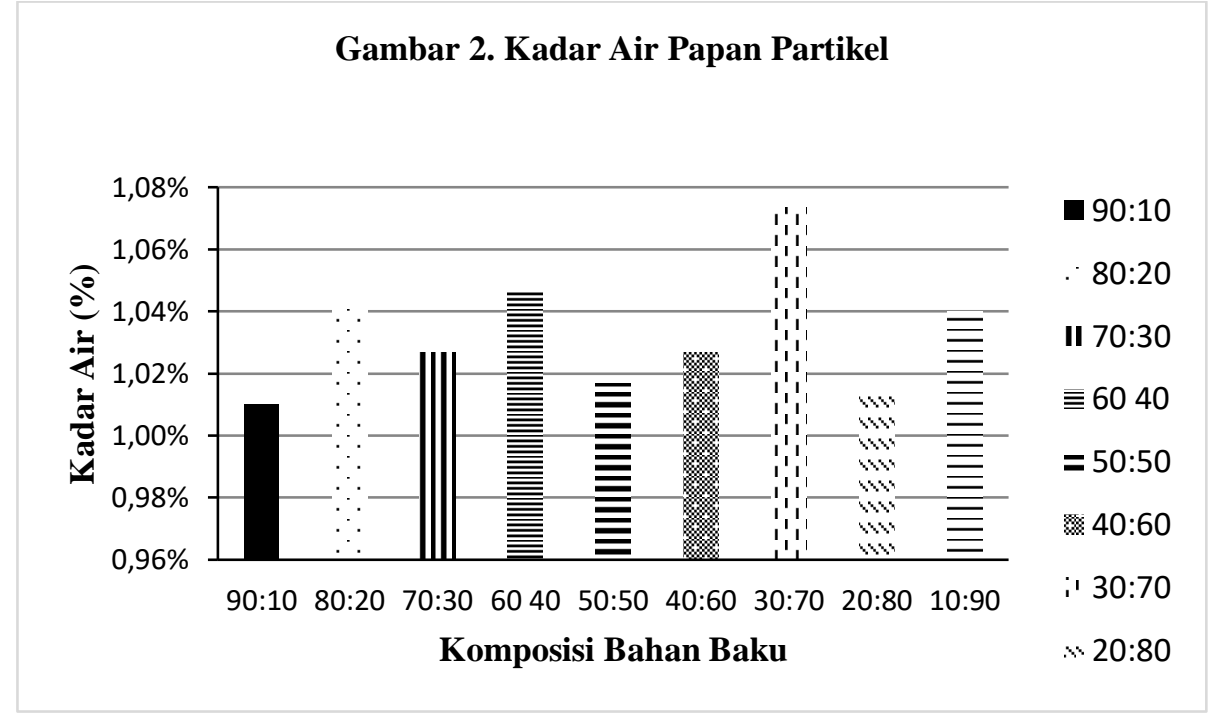

Gambar diatas menunjukkan nilai kadar air papan partikel yang dihasilkan antara 1,01- $1,07 \%$. Nilai kadar air terendah papan partikel terdapat pada papan dengan komposisi 90\%:10\% dan 20\%:80\% yaitu 1,01\%, sedangkan nilai kadar air tertinggi papan partikel terdapat pada komposisi 30\%:70\% yaitu 1,07\%. Nilai kadar air papan partikel diatas telah memenuhi nilai yang ditetapkan SNI 03-2105-2006 yaitu < 14\%. Papan partikel yang dihasilkan pada pengujian ini sangat baik dikarenakan kecilnya angka kadar air yang terdapat pada papan partikel. Hal tersebut disebabkan oleh proses pengeringan bahan baku selama 7 hari dan dioven pada suhu $105^{\circ} \mathrm{C}$ (Rofaida, Pratama, Sugiartha, \& Widianty, 2021). Penggunaan perekat resin sebanyak 50\% berpengaruh pada kadar air papan partikel. Mengemukakan semakin besar jumlah perekat yang digunakan maka kadar air akan semakin kecil. Pengepresan juga dapat mempengaruhi kadar air pada papan partikel. Pengepresan dapat menyebabkan Penguapan air dan bahan kimia pada papan partikel sehingga banyak rongga sel yang kosong terbentuk. Oleh karena itu pada saat pendiaman selama 14 hari, kadar air pada papan partikel dapat lebih tinggi (Ratri Yuli Lestari, 2013). Kandungan bahan kima berupa selulosa dan hemiselulosa pada bahan baku juga berpengarug terhadap kadar air papan partikel dikarenakan bahan ini bersifat Hidrofilik (menyukai air) (Ngadianto, Aryo F, 2016). 


\section{Daya Serap Air}

Pengukuran kadar air memakai contoh uji berdimensi $10 \mathrm{~cm} \times 10 \mathrm{~cm} \times 1 \mathrm{~cm}$. Kandungan air dihitung dengan menimbang berat awal (BA) serta berat kering oven (BKO) dimana papan dioven dengan temperatur $105^{\circ} \mathrm{C}$ sepanjang 24 jam setelah itu ditimbang beratnya.

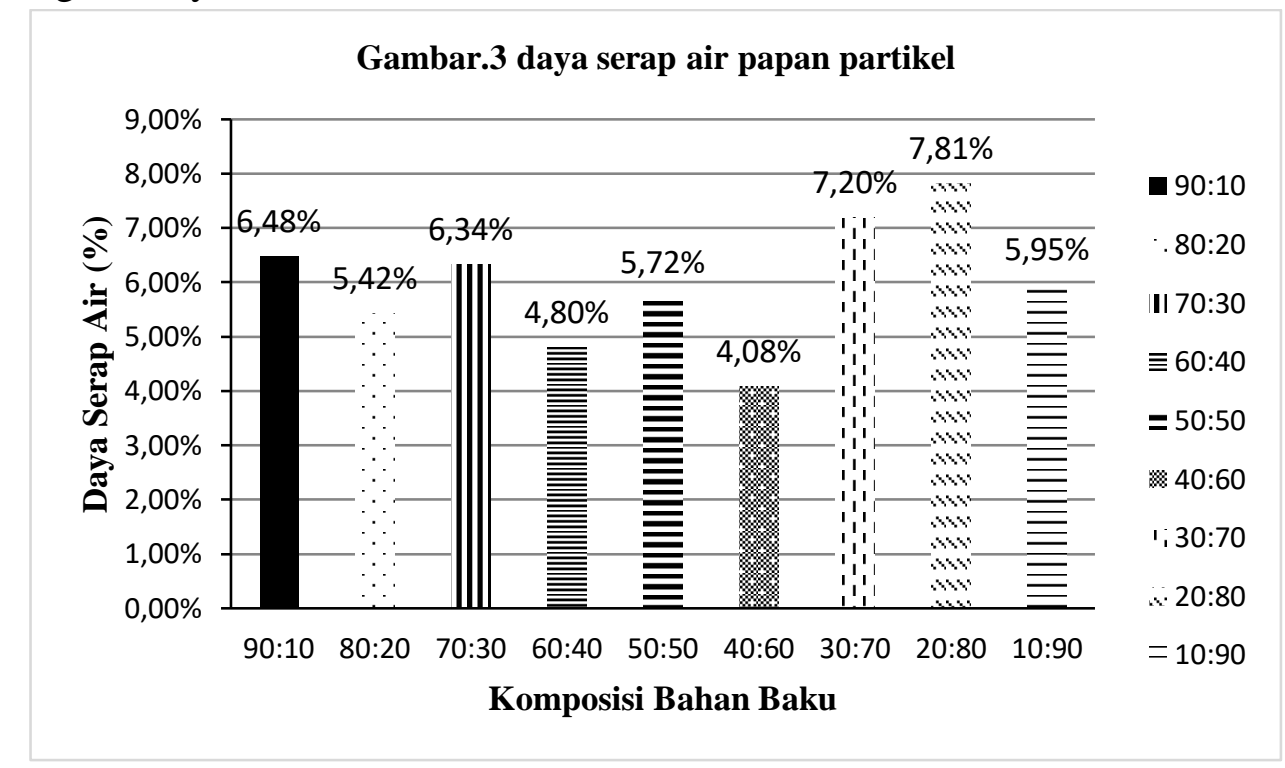

Gambar 3 memperlihatkan nilai daya serap air papan partikel setelah perendaman selama 24 jam adalah 4,08\%-7,81\%. Nilai daya serap air terendah setelah perendaman 24 jam terdapat pada komposisi 40\%:60\% yaitu 4,08\%, sedangkan nilai daya serap air tertinggi terdapat pada komposisi 20\%:80\% yaitu 7,81\%. Berdasarkan nilai tersebut maka hasil penelitian menunjukkan bahwa pengujian sifat fisis dan mekanis papan partikel telah memenuhi SNI 03-2105-2006 yakni tidak melebihi 14\%. Lama waktu pengempaan berpengaruh terhadap daya serap air semakin lama waktu pengempaan maka semakin sedikit daya serap air papan partikel ( Sudiryanto, 2015). Perekat yang digunakan pada pembuatan papan partikel juga berpengaruh terhadap daya serap air. Perekat yang mempunyai sifat gugus atom dapat mengikat bahan-bahan lain dengan maupun adsorpsi secara kimia sehingga jika papan partikel yang menggunakan perekat jenis ini direndam, maka akan terhidrolisa oleh air sehingga ikatan antar partikel semakin lemah sehingga dimensi papan lebih mudah terdegradasi (Raharjo, 2020). Kadar perekat juga mempengaruhi daya serap air semakin tinggi kadar air semakin rendah daya serap air (Sonjaya \& Haryanto, 2013). Peningkatan suhu pengempaan dapat menurunkan daya serap air pada papan partikel semakin tinggi suhu maka semakin rendah daya serap air (Kartika \& Desti, 2015). Penurunan tekanan saat pengempaan juga dapat menurunkan daya serap air semakin rendah tekanan maka semakin rendah daya serap.

\section{Pengembangan tebal}

Hasil pengujian Pengembangan Tebal dapat dilihat pada Gambar 4. 


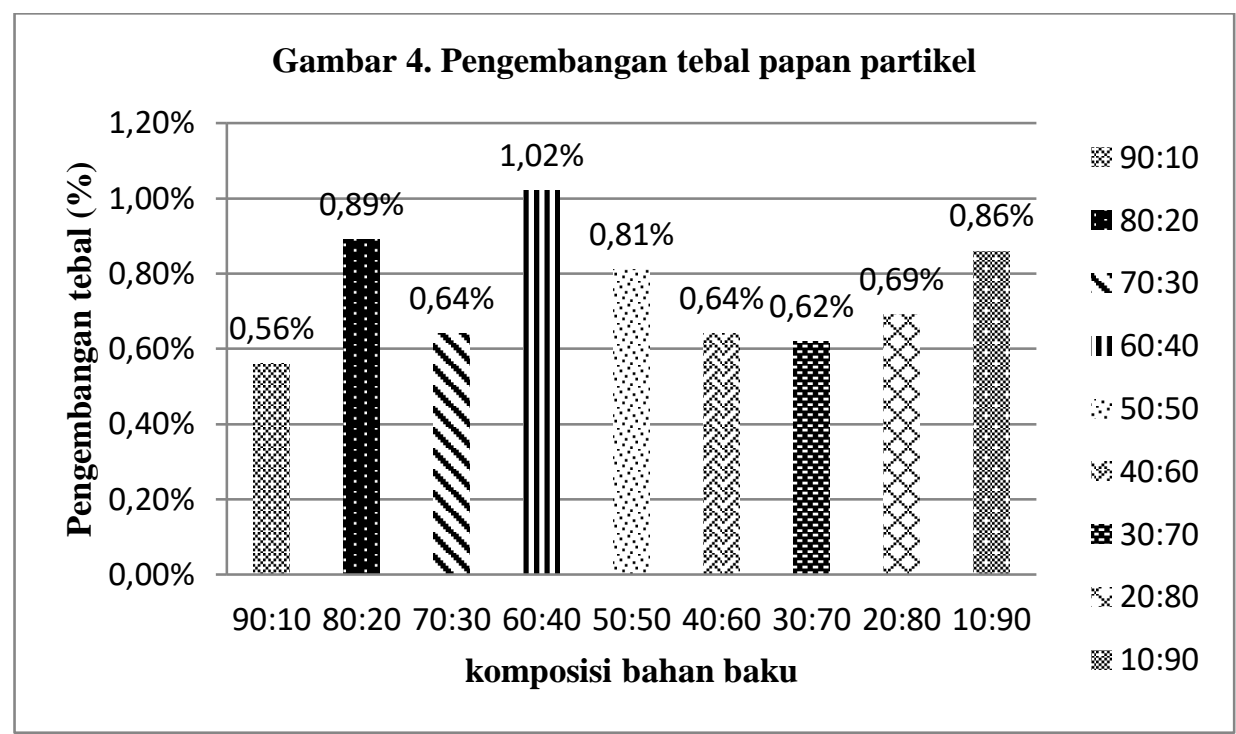

Gambar 4 memperlihatkan nilai pengembangan tebal papan partikel setelah perendaman selama 24 jam adalah $0,56 \%-1,02 \%$. Nilai pengembangan tebal terendah setelah perendaman 24 jam terdapat pada komposisi $90 \%: 10 \%$ yaitu $0,56 \%$, sedangkan nilai daya serap air tertinggi terdapat pada komposisi 60\%:40\% yaitu 1,02\%. Berdasarkan nilai tersebut maka Hasil penelitian menunjukkan bahwa pengujian sifat fisis dan mekanis papan partikel telah memenuhi SNI 03-2105-2006 yakni maksimum 12\%. Perekat resin dapat memenuhi seluruh papan partikel dengan baik apabila dibuat dengan konsentrasi yang tepat sehingga akan menekan nilai pengembangan tebal papan partikel (Raharjo, 2020). Kestabilan dismensi papan berpengaruh pada pengembangan tebal papan partikel semakin stabil dimensi papan maka semakin rendah pengembangan tebal papan partikel (Kartika \& Desti, 2015). Kadar perekat juga mempengaruhi pengembangan tebal papan partikel semakin tinggi kadar perekat semakin rendah pengembagan tebal (Sonjaya \& Haryanto, 2013). Sifat bahan baku berpengaruh terhadap pengembangan tebal papan partikel semakin tinggi daya absorbs air bahan baku maka semakin tinggi pengembangan tebal papan partikel (Raharjo, 2020). Waktu pengempaan yang lebih lama juga dapat menurunkan nilai pengembangan tebal (Ngadianto, Aryo F, 2016).

\section{Sifat Mekanik}

\section{Modulus of Elasticity (MOE)}

Modulus of Elasticity (MOE) Modulus of Elasticity (MOE) merupakan ukuran ketahanan papan partikel menahan beban sebelum patah. Dalam penelitian ini dilakukan pengujian menggunakan alat Universal Testing Machine (UTM) untuk memperoleh nilai MOE papan partikel yang dihasilkan. Hasil pengujian MOE papan partikel ditunjukkan pada Gambar 5. 


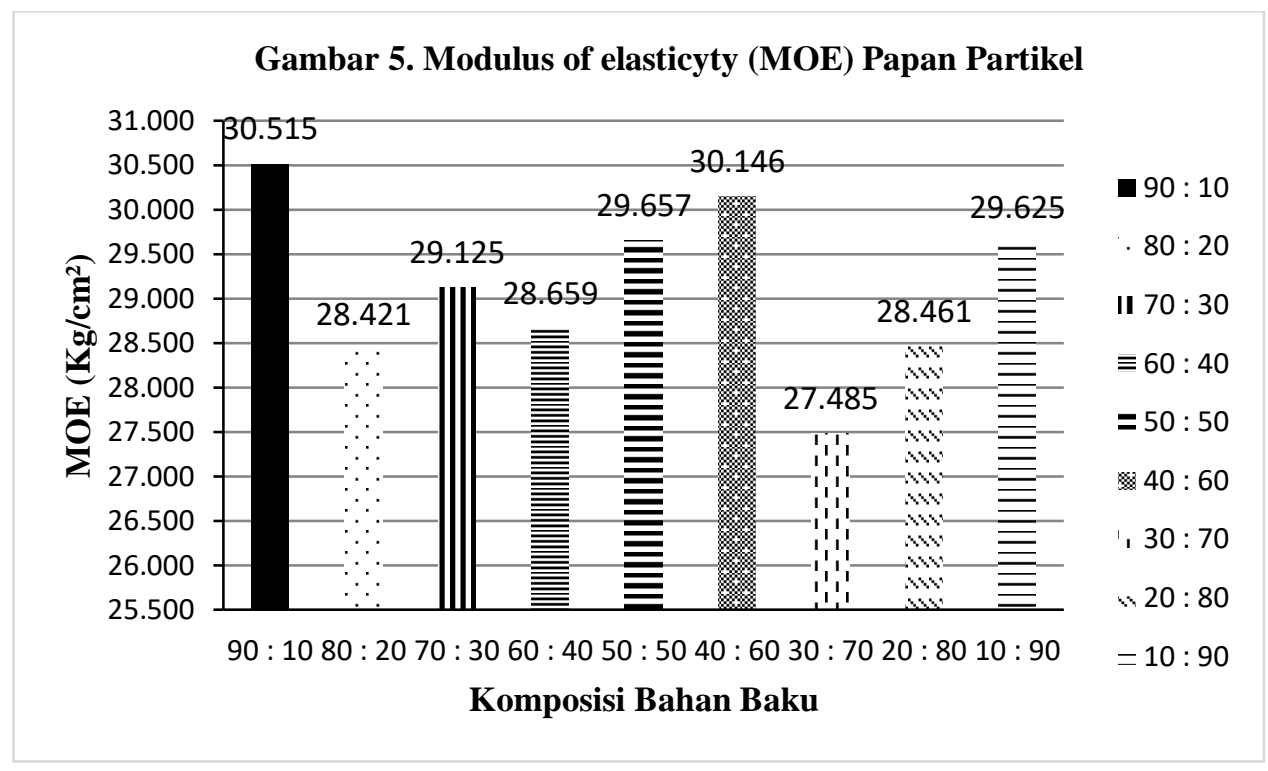

Tabel diatas menunjukan nilai MOE terendah papan partikel terdapat pada komposisi 30\%:70\% sebesar 27,485 kg/ $\mathrm{cm}^{2}$, sedangkan nilai MOE tertinggi terdapat pada papan dengan komposisi $90 \%: 10 \%$ yaitu $30,515 \mathrm{~kg} / \mathrm{cm}^{2}$. Pengujian yang didapat untuk semua variasi komposisi telah memenuhi standar SNI 03-2105-2006 yang mensyaratkan nilai MOE papan partikel yaitu minimum $20.400 \mathrm{~kg} / \mathrm{cm} 2$. Papan partikel dengan komposisi 90\%:10\% memiliki kondisi yang terbaik dibandingkan komposisi lain. Hal ini disebabkan karena papan partikel dengan komposisi ini menyebabkan bentuk geometri papan yang terbentuk lebih rapat. Akibatnya, sedikit pori-pori yang terbentuk karena komposisi yang sama saling mengikat. Ketika ditambahkan resin (50\%) maka matriks akan mengisi pori-pori atau rongga dari papan tersebut (Nasution \& Mora, 2018). Lama pengempaan dapat berpengaruh terhadap nilai MOE papan partikel hal ini disebabkan penambahan waktu kempa panas sampai titik plastisitas bahan mempunyai efek menurunkan kekuatan serat pemanasan dengan pengempaan sekaligus akan membuat lapisan serat menjadi menurun kekuatannya bila titik plastisitas terlampaui (Ngadianto, Aryo F, 2016). Kerapatan berpengaruh juga terhadap MOE papan partikel semakin tinggi nilai kerapatan semakin tinggi nilai MOE papan partikel (Aminah Lestari \& Mora, 2018). Bahan baku juga dapat mempengaruhi papan partikel jika bahan baku memiliki serat yang pendek maka nilai MOE papan akan semakin rendah.

\section{Modulus of Rupture (MOR)}

Modulus of Rupture (MOR) papan partikel merupakan sifat mekanis yang menunjukkan kekuatan material dalam menahan beban yang bekerja terhadapnya sampai patah. Berdasarkan hasil pengukuran didapatkan hasil pengujian MOR seperti pada Gambar 6. 


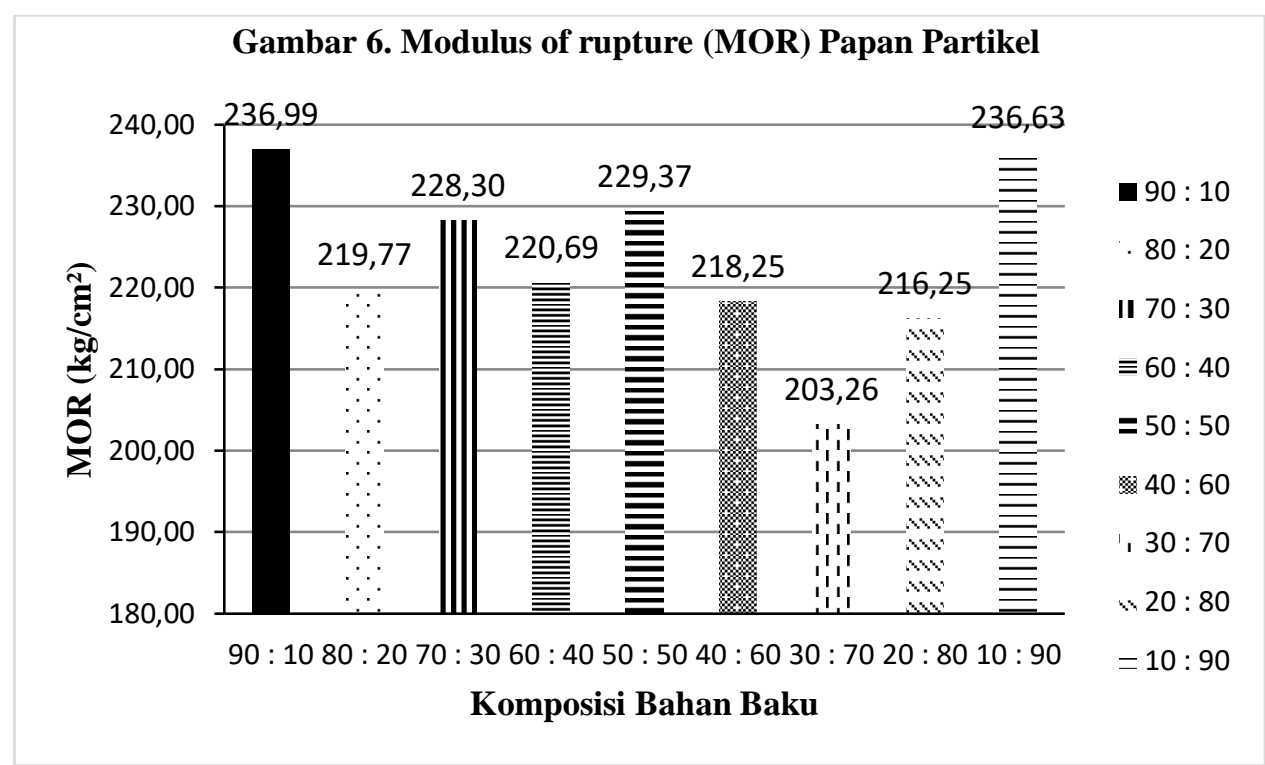

Gambar 6 memperlihatkan bahwa nilai hasil pengujian MOR antara 203,26$236,99 \mathrm{~kg} / \mathrm{cm}^{2}$. Nilai MOR terendah papan partikel terdapat pada papan dengan komposisi 30\%:70\% yaitu 203,26 kg/cm² sedangkan nilai MOR tertinggi terdapat pada papan dengan komposisi 90\%:10\% yaitu 236,99 kg/ $\mathrm{cm}^{2}$. Nilai MOR yang didapatkan untuk seluruh variasi komposisi papan partikel yang didapatkan pada penelitian ini memenuhi standar papan partikel Berdasarkan standar SNI 03-2105-2006 nilai MOR papan partikel yang ditetapkan minimal $82 \mathrm{~kg} / \mathrm{cm}^{2}$. faktor suhu pengempaan memberikan pengaruh yang sangat nyata terhadap MOE (Raharjo, 2020). Nilai MOR papan partikel berkaitan dengan proses perekatan protein dan serat. Semakin kuat ikatan antara matriks (protein) dan struktur penguat (serat) maka akan semakin baik nilai MOR papan partikel yang dihasilkan (Kartika \& Desti, 2015). Kadar perekat dapat mempengaruhi nilai MOR papan semakin tinggi kadar perekat maka semakin tinggi nilai MOR papan partikel (Sonjaya \& Haryanto, 2013.). Pengempaan dan pemanasan yang dilakukan sekaligus membuat lapisan serat menurun kekuatannya bila titik plastisitas terlampaui. Penurunan ini berhubungan langsung dengan nilai MOR papan partikel (Ngadianto, Aryo F, 2016). Perekat yang di pakai dalam pembuatan papan partikel juga harus dicapur secara merata karena dapat mempengaruhi nilai MOR papan partikel (aharjo, 2020).

\section{Keteguhan Rekat (Ib)}

Keteguhan rekat berkaitan dengan kualitas pembuatan papan partikel karena menunjukkan kekuatan ikatan antara partikelpartikelnya. Berdasarkan hasil pengukuran didapatkan hasil pengujian MOR seperti pada Gambar 6. 


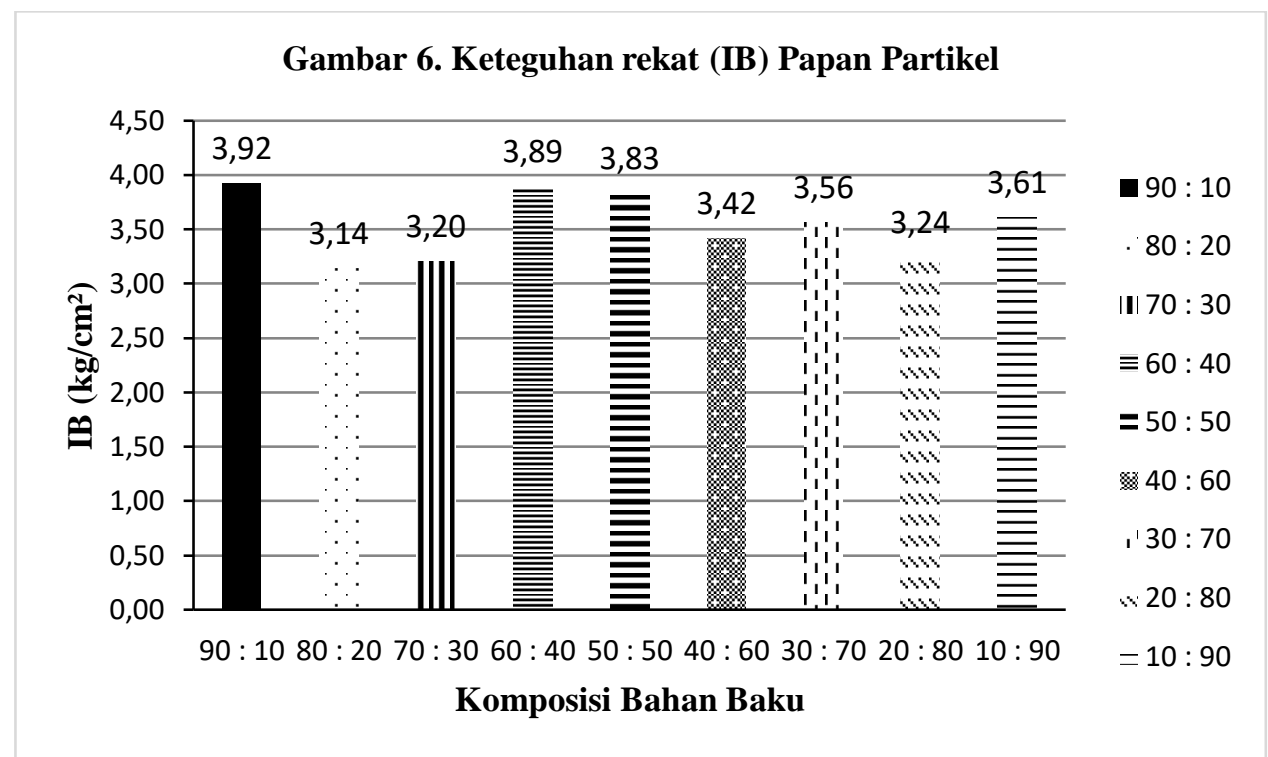

IB papan partikel yang dihasilkan dalam penelitian ini berkisar antara 3,14-3,92 $\mathrm{kgf} / \mathrm{cm}^{2}$. Nilai tertinggi adalah 3,92kgf/ $\mathrm{cm}^{2}$ pada komposisi papan 90\%:10\% sedangkan nilai terendah adalah $3,14 \mathrm{kgf} / \mathrm{cm}^{2}$ pada komposisi papan 80\%:20\%. Sehingga IB papan partikel didalam penelitian ini telah memenuhi syarat mutu SNI 03-2105-2006 yaitu $\geq 1,5$ $\mathrm{kgf} / \mathrm{cm}$. IB papan partikel semakin meningkat seiring dengan peningkatan suhu dari $150^{\circ} \mathrm{C}$ hingga $170^{\circ} \mathrm{C}$ dan cenderung menurun ketika suhu ditingkatkan hingga $190^{\circ} \mathrm{C}$. Faktor yang dapat menurunkan nilai IB papan perekat juga dipengaruhi oleh lamanya pengempaan papan partikel semakin lama pengempaan maka semakin rendah nilai IB papan partikel (Ngadianto, Aryo F, 2016). Jenis perekat juga mempengaruhi nilai IB papan partikel sifat perekat yang mampu mengikat partikel dengan baik seperti resin dan UF adalah perekat yang biasa di gunakan dalam pembuatan papan partikel dan dapat mengikat partikel dengan baik (Malau, Sucipto, \& Iswanto, 2016). Semakin banyak hemiselulosa yang terdegrasi pada bahan baku pada saat pengempaan akan menaikan nilai IB papan partikel (Kurniati, Kartika, Fahma, \& Sunarti, 2014). Ikatan yang rendah oleh kandungan zat kimia seperti lignin, minyak, silika pada serat sawit dapat mempengaruhi kekuatan IB.

\section{Kesimpulan}

Berdasarkan penelitian yang telah dilakukan dapat diambil kesimpulan bahwa hasil penelitian menunjukkan adanya pengaruh kecuali pada daya serap air dan modulus of elasticity pada komposisi papan partikel. Pada pengukuran sifat fisis dan mekanis didapatkan papan dengan kualitas terbaik pada komposisi 90\%:10\% dengan nilai kerapatan sebesar $1,10 \mathrm{~g} / \mathrm{cm}^{3}$, nilai kadar air $1,01 \%$, nilai pengembangan tebal terbaik sebesar 0,56\%, nilai MOE terbaik sebesar 30,515 kg/cm² pada komposisi 90\%:10\%, dan nilai MOR sebesar $236,99 \mathrm{~kg} / \mathrm{cm}^{2}$. Hasil penelitian menunjukkan bahwa pengujian sifat fisis dan mekanis papan partikel telah memenuhi standard SNI 03-2105-2006. 
Mutu Papan Partikel dari Campuran Batang dan Cangkang Kelapa Sawit (Elaeis Guineensis Jacq) dengan Penggunaan Resin

\section{Bibliografi}

Diharyo, Salampak, Damanik, Zafrullah, \& Gumiri, Sulmin. (2020). Pengaruh Lama Aktifasi Dengan H3po4 Dan Ukuran Butir Arang Cangkang Kelapa Sawit Terhadap Ukuran Pori Dan Luas Permukaan Butir Arang Aktif. PROSIDING SEMINAR NASIONAL LINGKUNGAN LAHAN BASAH, 5(1), 48-54.

Iskandar, M. I., \& Supriadi, Achmad. (2017). Karakteristik Papan Partikel Dari Bulu Domba, Serbuk Gergaji Dan Serutan Kayu Dengan Perekat Urea Formaldehida. JURNAL SAINS NATURAL, 5(1), 9-16.

Johari, Agung Fahmi, Kardiman, Kardiman, \& Santoso, Deri Teguh. (2021). Pengaruh Temperatur terhadap Pembuatan Papan Komposit Sekam Padi Berbasis Limbah HDPE menggunakan Metode Hot Press. Jurnal Rekayasa Mesin, 16(1), 17-24.

Kartika, Ika Amalia, \& Desti, Herdiarti. (2015). Pembuatan Papan Partikel Dari Bungkil Jarak Kepyar (Ricinus Communis L.) Dengan Perlakuan Pendahuluan Steam Explosion. E-Jurnal Agro-Industri Indonesia, 4(1).

Kurniati, Mersi, Kartika, Ika Amalia, Fahma, Farah, \& Sunarti, Titi Candra. (2014). Sifat Fisik Dan Mekanik Papan Partikel Dari Ampas Jarak Kepyar Physical And Mechanical Properties Of Particle Board From Castor Cake Meal.

Lestari, Aminah, \& Mora, Mora. (2018). Pengaruh Variasi Massa Batang Pisang dan Cangkang Kelapa Sawit terhadap Sifat Fisis dan Mekanis Komposit Papan Partikel Menggunakan Perekat Resin Epoksi. Jurnal Fisika Unand, 7(2), 124-129.

Lestari, Ratri Yuli. (2013). PROPERTIES OF BINDERLESS PARTICLEBOARDS FROM OIL PALM EMPTY FRUIT BUNCH (Elaeis guineensis Jacq.). Widyariset, 16(2), 219-226.

Malau, Johanna Christina, Sucipto, Tito, \& Iswanto, Apri Heri. (2016). Kualitas Papan Partikel Batang Pisang Barangan Berdasarkan Variasi Kadar Perekat Phenol Formaldehida. Peronema Forestry Science Journal, 5(1), 1-9.

Mawardi, Indra. (2009). Mutu Papan Partikel dari Kayu Kelapa Sawit (KKS) Berbasis Perekat Polystyrene. Jurnal Teknik Mesin, 11(2), 91-96.

Nasution, Widi Mulia, \& Mora, Mora. (2018). Analisis Pengaruh Komposisi Partikel Ampas Tebu dan Partikel Tempurung Kelapa terhadap Sifat Fisis dan Mekanis Komposit Papan Partikel Perekat Resin Epoksi. Jurnal Fisika Unand, 7(2), 117123.

Ngadianto, Aryo F, Primadani G. (2016). Karakteristik Papan Partikel Dari Pemanfaatan Limbah Sabut Kelapa Dan Mending. Yogyakarta: Pengelolaan Hutan, Sekolah Vokasi Universitas Gadjah Mada. 
Calvin Davidson Silalahi ${ }^{1}$, Rama R. Sitinjak ${ }^{2}$, dan Bayu Pratomo ${ }^{3}$

Radam, Rosidah, Soendjoto, Mochamad Arief, Rezekiah, Hj, \& Agustina, Arfa. (2018). Pengaruh kerapatan terhadap pengembangan tebal dan penyerapan air papan partikel dari sabut kulit buah nipah. Prosiding Seminar Nasional Teknologi Hasil Hutan 2018, 169-177. Forestry Faculty, Lambung Mangkurat University.

Raharjo, Buwang. (n.d.). Pemanfaatan Limbah Tandan Kosong Kelapa Sawit sebagai Bahan Pengganti Alternatif Papan Partikel. Indonesian Journal of Laboratory, 2(1), $1-9$.

Rofaida, Aryani, Pratama, Rizki Mikroji, Sugiartha, I. Wayan, \& Widianty, Desi. (2021). SIFAT FISIK DAN MEKANIK PAPAN PARTIKEL AKIBAT PENAMBAHAN FILLER SERAT BAMBU. Spektrum Sipil, 8(1), 1-11.

Sonjaya, Muhammad Lutfi, \& Haryanto, Iman. (n.d.). PENGARUH KOMBINASI LAPISAN PAPAN PARTIKEL DARI LIMBAH PARTIKEL AREN (Arenga pinnata) DAN LIMBAH SERUTAN BAMBU (Dendrocalamus asper) DENGAN JUMLAH PEREKAT UREA FORMALDELHIDA TERHADAP SIFAT PAPAN PARTIKEL. ASEAN Journal of Systems Engineering, 1(1).

Sudiryanto, Gun. (2015). Pengaruh suhu dan waktu pengempaan terhadap sifat fisik dan mekanik papan partikel kayu sengon (Paraserienthes Falcataria (L) Nielson). Jurnal DISPROTEK, 6(1). 